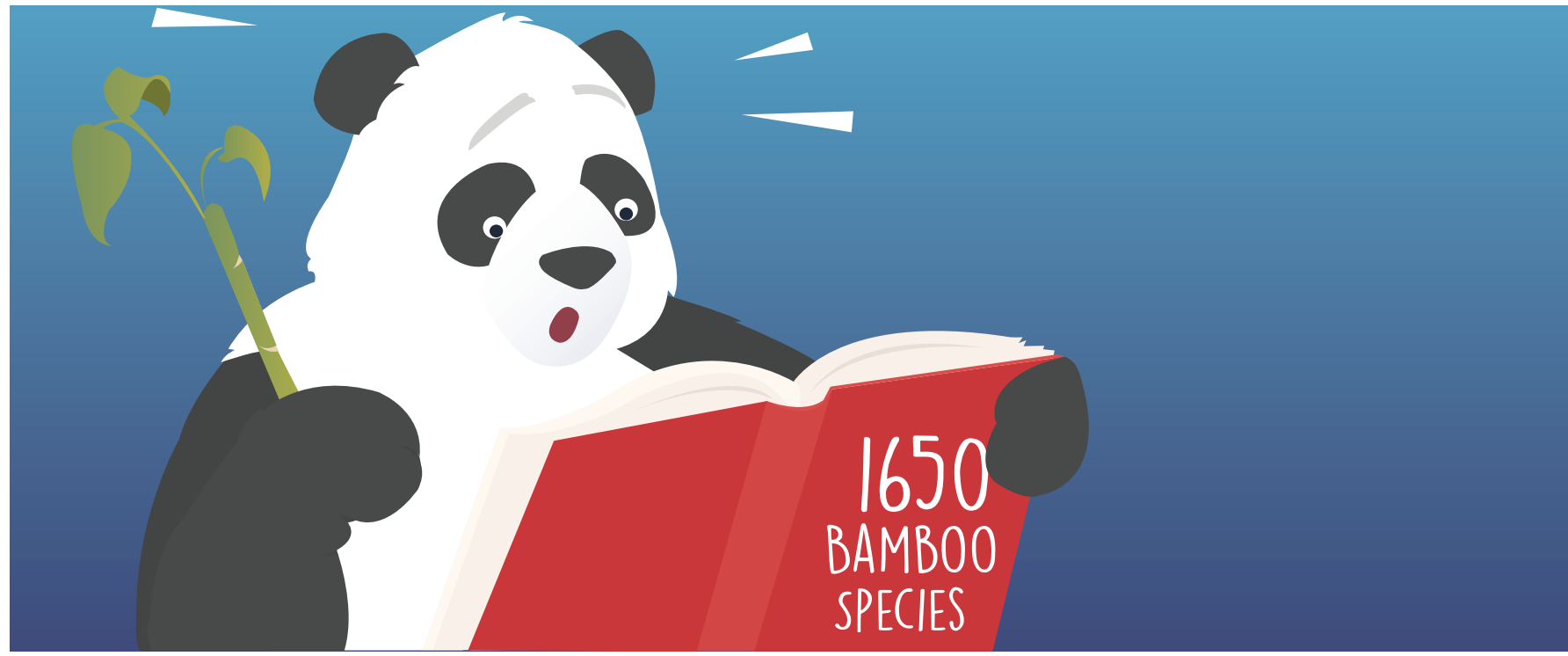

\title{
ARE THERE WILD BAMBOOS IN MEXICO?
}

\section{Eduardo Ruiz-Sanchez ${ }^{1 *}$ and Lynn G. Clark ${ }^{2}$}

${ }^{1}$ Departamento de Botánica y Zoología, Centro Universitario de Ciencias Biológicas y Agropecuarias, Universidad de Guadalajara, Zapopan, Mexico, ²Department of Ecology, Evolution, and Organismal Biology, lowa State University, Ames, IA, United States

\section{REVIEWED BY:}

LUANA AGE: 14
Bamboos, unlike other grasses, mostly live in association with forests. Two different types of bamboos are recognized: the thick, hard "woody" bamboos, reaching up to $40 \mathrm{~m}$ tall, and the softer-stemmed "herbaceous" bamboos, rarely reaching more than $1 \mathrm{~m}$ tall. Worldwide, over 1,650 bamboo species are known, and although many people think of bamboos as Asian, 530 species (about one-third of total bamboo diversity) are native to the Western hemisphere. With the exception of Canada, every country in the Americas has a least one bamboo species-even the USA has three. In this article, we will focus on the Mexican bamboo species. Mexico has 56 of the 530 bamboo species, of which 52 are woody bamboos and 4 are herbaceous bamboos. A total of 24 Mexican bamboo species live in the cloud forest, so this type of vegetation is very important for the bamboos of Mexico. Among those 56 species, 36 are found only in Mexico, which means they are endemic. Native bamboos in Mexico were used long before Spanish conquerors arrived and are still used today.

\section{BAMBOO, THE FOREST GRASS}

When you hear the word bamboo, what comes to your mind? We know what you are probably thinking-panda bears in China, correct? But did 


\section{FOREST}

UNDERSTORY

The vegetation under the main canopy on the forest floor.

POACEAE

The grass family scientific name.

\section{BAMBOO}

SCIENTIFIC

NAMES ENGLISH PRONUNCIATION

Arundinaria: u-run-di-NÂri-u; Chusquea: chusKWÊ-u; Guadua: GWÄdu-wu; Olmeca:

OL-mâ-ku; Otatea:

ô-tu-TÂ-u; Rhipidocladum: ri-pi-DOK-lu-dum.

NEOTROPICAL BAMBOOS

Herbaceous and woody bamboos living in the tropical areas of North, Central, and South America. you know that in the Americas (the Western hemisphere) we have more than 530 native bamboo species? Counting all the bamboo species in the world, including those that the panda eats, there are more than 1,650 species [1]. Bamboos are native to every single continent in the world, except for Antarctica and Europe. When you think about bamboo, you probably think about those giant grasses reaching up to $40 \mathrm{~m}$ tall with hard, jointed stems, and graceful branches. However, in the tropical rain forests from Mexico down to South America, there are also bamboos with softer, smaller stems, usually less than $1 \mathrm{~m}$ tall. One of these, from French Guiana, only grows $2 \mathrm{~cm}$ tall (less than $1^{2}$ high!) and is the world's smallest bamboo. The reason for this variability in bamboos is because there are two types of bamboos, the thick, hard "woody" bamboos that compete with trees for light, and the smaller "herbaceous" bamboos that live in the forest understory (the vegetation under the main canopy on the forest floor). And speaking of grasses, did you know that all the bamboos belong to the grass family (which has the scientific name Poaceae)? This means that the bamboos are cousins of lawn grass, corn, rice, wheat, sugar cane, and all the other grasses.

\section{BAMBOO DIVERSITY IN THE AMERICAS}

Every single country in the Americas has a least one species of native bamboo, with the exception of Canada. For example, the USA has three native species of the woody bamboo genus Arundinaria (see Bamboo scientific names English pronunciation). These three species are endemic to the USA, which means that they only live in the USA and not anywhere else in the entire world. However, the three North American bamboo species are not closely related to the Neotropical bamboo species that live from Mexico to Argentina and in the Caribbean Islands. The Neotropical bamboos include about 400 woody bamboo species and about 125 herbaceous bamboo species. The latest evolutionary tree of bamboos, which uses genetic similarities and differences to show how all of these bamboos are related to each other [2], confirms that the three North American bamboo species are more closely related to Asian bamboos rather than the Neotropical bamboos.

Of the 530 woody and herbaceous bamboo species living in the Americas [3], nearly $90 \%$ exist in three main regions. These regions have the highest bamboo diversity and the highest number of endemic species. Those regions are (1) Brazil, including the Atlantic forest and the Amazon basin; (2) the Central and Northern Andes mountains; and (3) Mexico and Central America. Brazil has the highest bamboo diversity by far, with 256 bamboo species, of which about 136 species are endemic to Brazil. The Andes has over 130 bamboo species, of which 110 species are endemic. Finally, Mexico and Central America have 87 bamboo species, of which about 52 species are endemic. 


\section{ENDEMISM}

A species (endemic species) is restricted to a particular geographic region.

\section{FIGURE 1}

Map of Mexico, with black circles showing the sites where a least one species of native bamboo has been collected.

A. Cryptochloa strictiflora, herbaceous bamboo.

B. Guadua aculeata, the tallest woody bamboo species in México.

\section{MEXICAN BAMBOO SPECIES}

Mexico has 56 of the 530 American bamboo species growing within its borders. Fifty-two of them are woody bamboo species and only four are herbaceous bamboo species (Figure 1). Among those 52 woody bamboo species, 36 are endemic to Mexico, which means that $69 \%$ of Mexican bamboo diversity lives only in Mexico. Did you notice a distribution pattern of species diversity and endemism of the American bamboos? To the south, Brazil has the highest diversity of bamboo species; moving to the northwest in the Andes, the diversity is less than in Brazil but with more endemic species; and moving north to Mexico, both diversity and endemism decrease. The same southnorth pattern of diversity and endemism is repeated in Mexico. The southern state of Chiapas has the highest diversity, with 32 species (both woody and herbaceous), followed by Veracruz, with 25 species and Oaxaca, with 23 species. If we move to the northeast in Nuevo Leon, we can find only one bamboo species, and moving to the northwest in Sonora, where we also find only one species, the same pattern is observed.

Let's get to know some of the Mexican bamboo species. We will begin with the herbaceous bamboos. Did you remember that, in Mexico, there are only four herbaceous species? One of them is Cryptochloa strictiflora which is the smallest herbaceous bamboo species in Mexico and only reaches $20 \mathrm{~cm}$ in height (Figure 1A). This species lives exclusively in the tropical rainforest at elevations less than $900 \mathrm{~m}$ above sea level (asl).

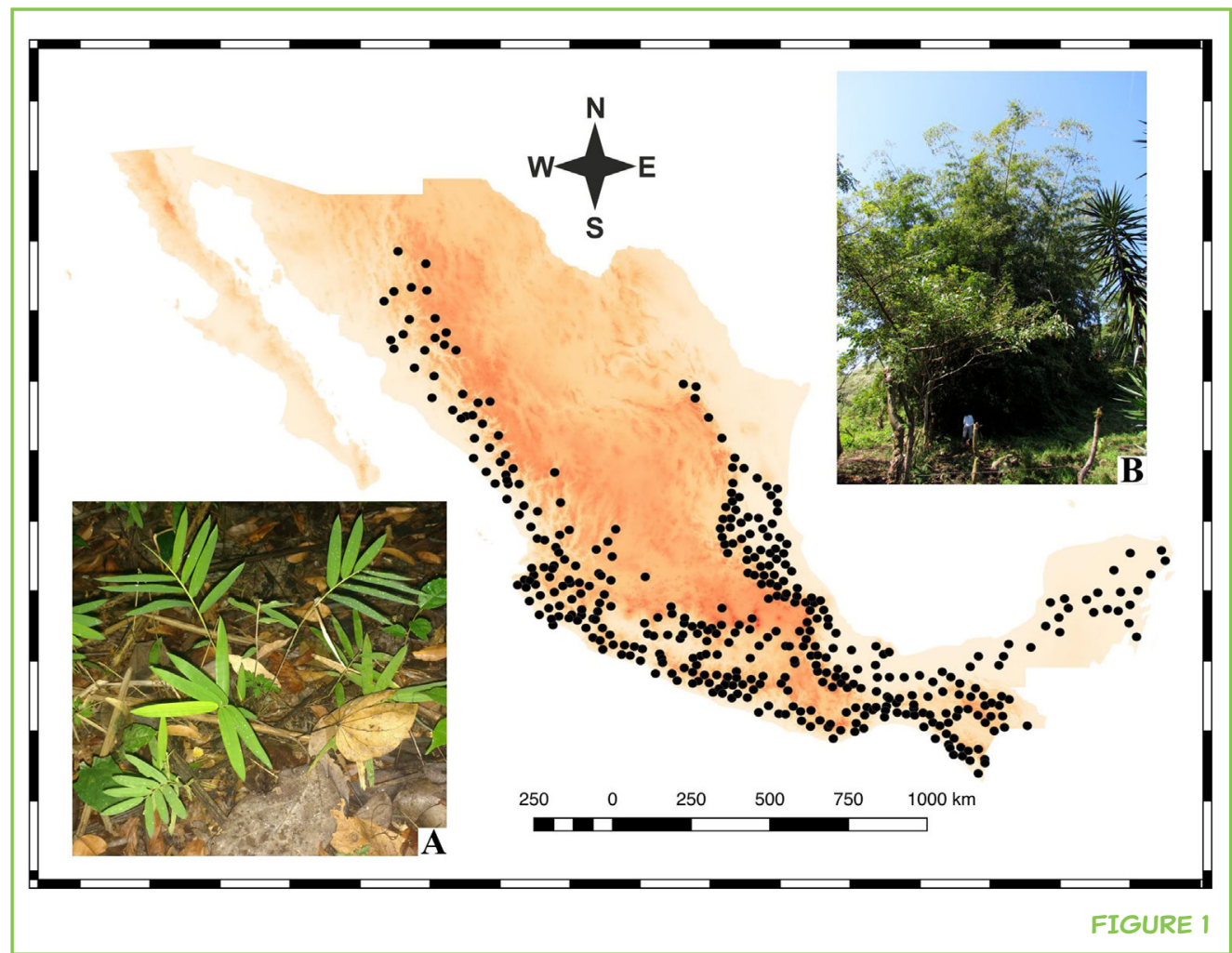




\section{CLOUD FOREST}

Mountain forests with persistent clouds or fog that provide much of the available moisture.

\section{CONIFEROUS FORESTS}

Forests dominated by pines and other coneproducing trees.

TROPICAL RAIN FOREST

Forests in which trees lose their leaves for only a short period.

\section{FIGURE 2}

Four native Mexican bamboo species. A. Fleshy fruits of Olmeca reflexa. B. Otatea acuminata in state of Oaxaca. C. Dr. Lynn Clark in front of Chusquea enigmatica, the smallest woody bamboo species in Mexico. D. Branches of Rhipidocladum racemiflorum from veracruz.
The woody bamboos in Mexico are represented by 8 genera and 52 species. Chusquea enigmatica is the smallest species of woody bamboo that grows in Mexico in the cloud forest (mountain forests with persistent clouds or fog that provide much of the available moisture), reaching a height of $40 \mathrm{~cm}$ to $100 \mathrm{~m}$ (Figure 2C). Chusquea bilimekii is the Mexican species that lives at the highest elevation, at around 3,150 m asl, in coniferous forests (forests dominated by pines and other cone-producing trees) on volcanoes. Two other species that live in the coniferous forest are C. matlatzinca and C. septentrionalis, the latter being the most recently discovered new bamboo species in Mexico. There are in total 22 Chusquea species, and 14 of them live in the cloud forest. The tallest woody bamboo species of Mexico is Guadua aculeata that grows more than $20 \mathrm{~m}$ in height (Figure 1B). This species is used to build houses in the region of the Gulf of Mexico, particularly in the Puebla and Veracruz states.

Olmeca, another woody bamboo genus, has five species, with four of them endemic to Mexico and three of them living in the cloud forest. Do you know that the Olmeca's name is in honor to the Olmec ethnic group, who inhabited southern Veracruz and Tabasco between 400 and 700 B.C.? Olmeca recta and O. reflexa live in the tropical rain forest at low elevation (0-900 $\mathrm{m}$ asl) and both species produce unusual and fascinating fleshy fruits (Figure 2A). (The fruit of most bamboos looks like a grain of rice or wheat.) Another woody genus, Otatea, has 12 species, 10 of them endemic to Mexico. Otatea victoriae lives in seasonally dry scrubby vegetation. This last species is fascinating because it is
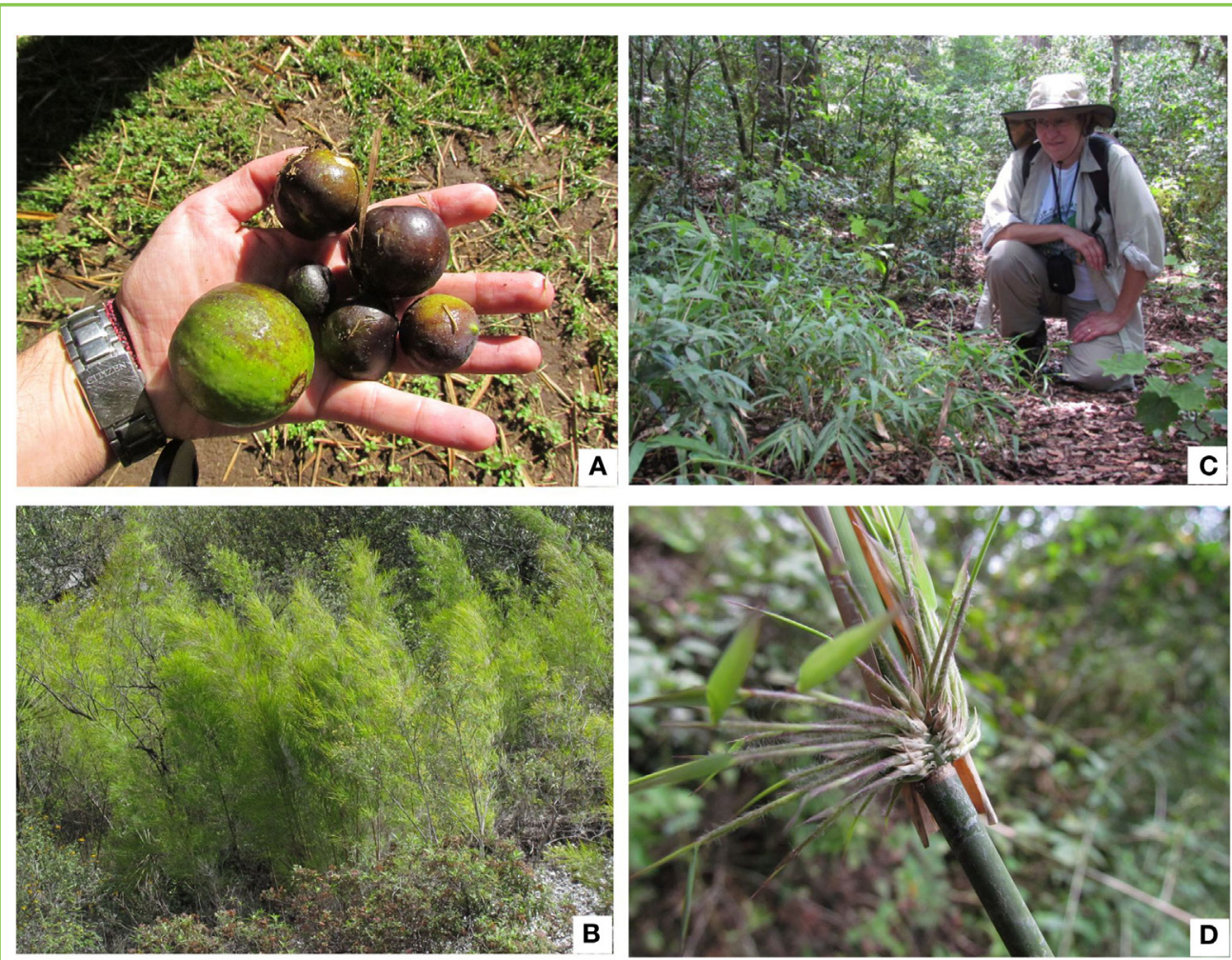

FIGURE 2 


\section{EPIPHYTES}

Plants such as mosses that grow on other plants, mainly trees.

\section{FIGURE 3}

Some uses of Mexican bamboo species. A.,

B. Various uses (baskets, walking sticks, and door) made with the culms of Otatea acuminata. C.,D. Two walls (bajereque) using Otatea fimbriata C. and Guadua paniculata D. one of the most drought-tolerant bamboos in the world. The Rhipidocladum genus has only four species in Mexico and only one of them is endemic that lives in the cloud forest. The species of this genus have branches in the form of a fan (Figure 2D) [4].

Did you notice that some of the Mexican bamboo species live in the cloud forest? Probably not, so we will tell you! A total of 24 Mexican bamboo species live in the cloud forest. Maybe are you thinking, "Why is this kind of forest important?" The cloud forest in Mexico, as well as in Central America and the northern Andes, is one of the more threatened types of environments. Less than $1 \%$ of the original total area remains and the rest has been replaced by other types of vegetation or croplands. However, cloud forests possess a great biodiversity, including epiphytes (plants such as mosses that grow on other plants, mainly trees) and many kinds of animals, and they capture and hold more water than other kinds of forests. The plant biodiversity that exists in the Mexican cloud forests reaches 2,500-3,000 species, which represents 10-12\% of the total plant species diversity in Mexico.

\section{BAMBOOS IN MEXICAN CULTURE}

Native bamboos in Mexico were used long before the Spanish conquerors arrived in the early sixteenth century. There is archeological evidence that some ethnic groups, such as the Aztecs and Olmecs among others, used bamboos

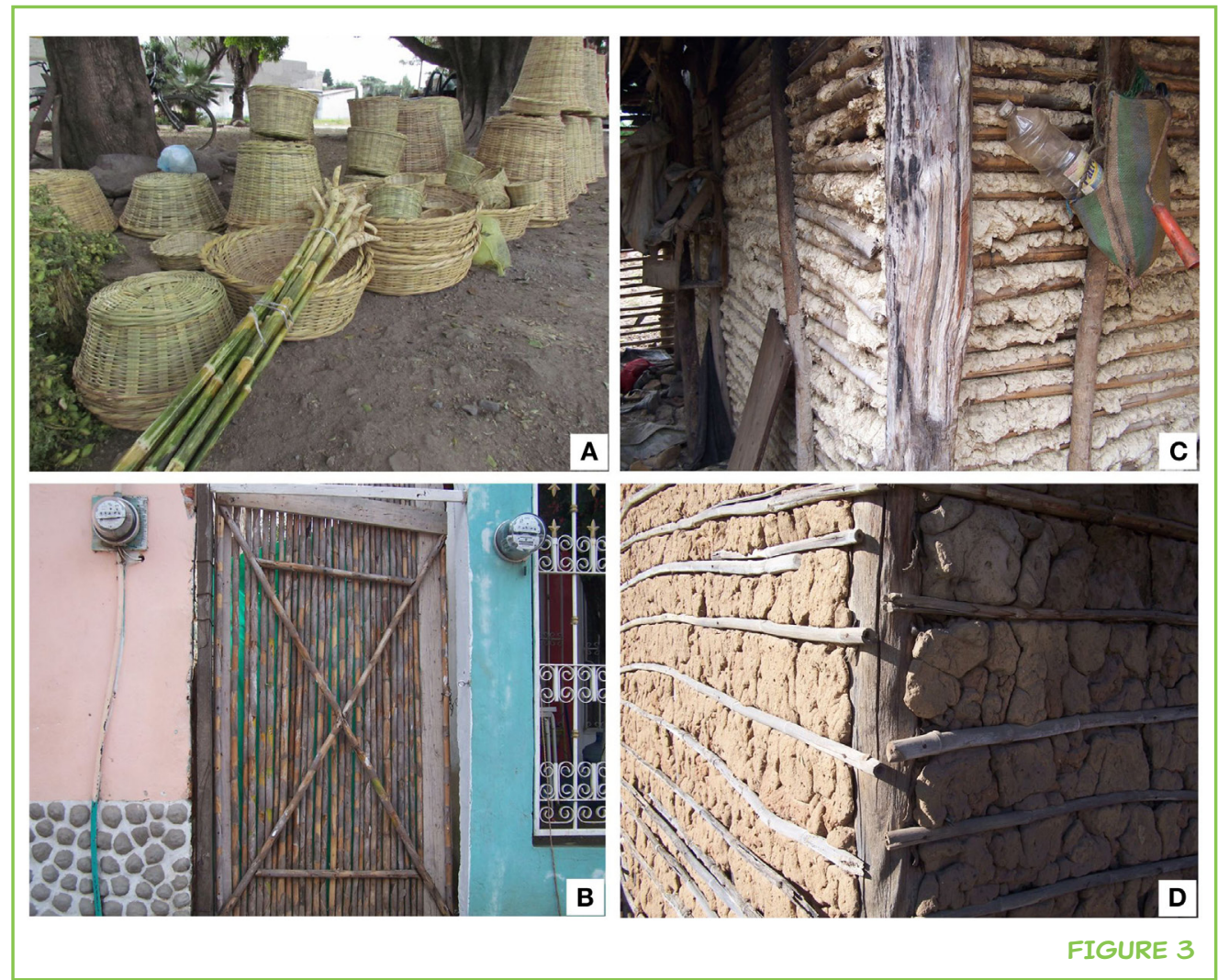


in their every-day lives. Of the 56 Mexican bamboo species, Otatea acuminata is by far the most abundant and widespread and is the most utilized species (Figures 2B and 3A,B). It is known as "otate," which means solid cane, a name derived from the Nahuatl "otatl," which means "cane." This species sometimes forms dense forests, known as "otatales." The name otate, however, is also given to some other bamboo species, or even to non-bamboo grasses. The most used part of Otatea acuminata and the other Mexican bamboo species is the culm (the name for the main cane). When used to build houses, the culms make up the framework and then are covered with mud to build walls, known as "bajereque" or "bahereque." Also, culms of this species are used to build roofs of rural houses, as well as doors, fences, baskets, walking sticks, and tool handles used in agriculture [5] (Figure 3). Just as some Mexican bamboo species are used to make houses, baskets, and handicrafts, other bamboo species are also used to do the same in South America, Asia, and Africa.

\section{CONCLUSION}

Now you know that the over 1,650 species of bamboos live not only in Asia; here in America we have at least 530 native species and in Mexico 56 species, including both bigger woody bamboos and smaller herbaceous bamboos. The Mexican bamboo species are widely distributed in Mexico and the cloud forest is one of the most important environments where most of the bamboo species live, but some Mexican bamboos also live in very dry places. Bamboos, especially otate, traditionally have been used for housing and various other purposes in Mexico and continue to be used in these ways. So, the next time that you see bamboo or hear the word bamboo, you will think of America and of Mexico, not just pandas and Asia.

\section{ACKNOWLEDGEMENTS}

We want to thank Ray Angelo for helping us with the English pronunciation of bamboo names.

\section{REFERENCES}

1. Vorontsova, M. S., Clark, L. G., Dransfield, J., Govaerts, R., and Baker, W. J. 2016. World Checklist of Bamboos and Rattans. Beijing, China: International Network of Bamboo and Rattan. INBAR Technical Report No.: 37. 466 p.

2. Wysocki, W. P., Clark, L. G., Attigala, L., Ruiz-Sanchez, E., and Duvall, M. R. 2015. Evolution of the bamboos (Bambusoideae; Poaceae): a full plastome phylogenomic analysis. BMC Evol. Biol. 15:50. doi:10.1186/s12862-015-0321-5 
3. Clark, L. G., Londoño, X., and Ruiz-Sanchez, E. 2015. Bamboo taxonomy and habitat. In Bamboo: The Plant and Its Uses. ed. W. Liese and M. Köhl (Vol. 10), 1-30. Switzerland: Springer International Publishing.

4. Ruiz-Sanchez, E., Clark, L. G., Londoño, X., Mejía-Saulés, M. T., and Cortés Rodríguez, G. 2015. Morphological keys to the genera and species of bamboos (Poaceae: Bambusoideae) of Mexico. Phytotaxa 236:1-24. doi:10.11646/ phytotaxa.236.1.1

5. Ruiz-Sanchez, E., Sosa, V., Mejía-Saulés, M. T., Londoño, X., and Clark, L. G. 2011. A taxonomic revision of Otatea (Poaceae: Bambusoideae: Bambuseae) including four new species. Syst. Bot. 36:314-36. doi:10.1600/036364411X569516

SUBMITTED: 04 September 2017; ACCEPTED: 05 January 2018; PUBLISHED ONLINE: 26 January 2018.

EDITED BY: Chelsea D. Specht, Cornell University, United States

CITATION: Ruiz-Sanchez E and Clark LG (2018) Are There Wild Bamboos in Mexico? Front. Young Minds 6:01. doi:10.3389/frym.2018.00001

CONFLICT OF INTEREST STATEMENT: The authors declare that the research was conducted in the absence of any commercial or financial relationships that could be construed as a potential conflict of interest.

COPYRIGHT (C) 2018 Ruiz-Sanchez and Clark. This is an open-access article distributed under the terms of the Creative Commons Attribution License (CC BY). The use, distribution or reproduction in other forums is permitted, provided the original author(s) and the copyright owner are credited and that the original publication in this journal is cited, in accordance with accepted academic practice. No use, distribution or reproduction is permitted which does not comply with these terms.

\section{REVIEWED BY}

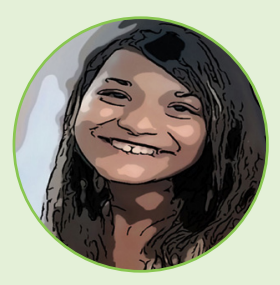

\section{LUANA, AGE: 14}

I'm 14 years old, and dogs are my favorite things in the world. For my future career, l'd love to become a Vet, specifically creating smart prosthetics that can communicate with the animals" nervous system.

\section{AUTHORS}

\section{EDUARDO RUIZ-SANCHEZ}

I did my Bachelor's in biology at the University of Guadalajara, Mexico with an emphasis on grasses. My Ph.D. was focused on the woody bamboo genus Otatea at the Institute of Ecology, Mexico. Since 2008, I have been studying Mexican bamboo species, and I have described 17 new species in collaboration with Dr. Lynn Clark and other bamboo specialists. Now I work as a professor at the University of Guadalajara, Mexico and I continue to study Mexican bamboo species. Every afternoon I like to walk with my dog 
"Filogenio" and on weekends I like to watch series on Netflix and read non-science books. *ruizsanchez.eduardo@gmail.com

\section{LYNN G. CLARK}

I have been studying bamboo for over 40 years. I did my Bachelor's degree in botany at Michigan State University and then did my Ph.D. on the woody bamboo genus Chusquea at lowa State University. In 1987, I became a professor at lowa State University and have been studying the diversity and evolution of bamboos and other grasses ever since. I also teach classes in plant systematics and plant anatomy. As part of my research, I collaborate with bamboo specialists throughout Latin America, including Dr. Eduardo Ruiz-Sanchez, and travel frequently to countries such as Mexico, Costa Rica, Brazil, Colombia, and Ecuador for field work. I have described over 100 new species of Neotropical bamboos. I live with my husband and three cats on a farm that we converted to tallgrass prairie, and we also have a big vegetable garden and a small orchard. 